\title{
ANALISIS PERSEPSI BMT PENGGUNA TERHADAP KUALITAS JASA PELAYANAN PPOB ABSINDO
}

\author{
Azfa Mutiara Ahmad Pabulo \\ Program Studi Akuntansi \\ Universitas Mercu Buana Yogyakarta \\ *apabulo@yahoo.com
}

\begin{abstract}
The purpose of this research is to study the differences in expectations of service quality in the use of BMT PPOB ABSINDO by users in Yogyakarta. The research instrument is a questionnaire to the user BMT PPOB ABSINDO which includes the dimensions of service quality in general (servqual / service quality) is a system PPOB ABSINDO Payment Point to conduct payment transactions of electricity, telephon, pulses and flight tickets and train tickets in BMT users. The sample was 30 users PPOB ABSINDO BMT in Yogyakarta. Hypothesis testing is done by using gap analysis, paired sample t test, $t$ test, and Cartesian diagram .

The results of the analysis of the study found a negative gap between expectations and the reality of the quality of services $P P O B A B S I N D O$ system. The differences between expectation and reality of the quality of services that include the dimensions of service quality in general about $P P O B A B S I N D O$ described in 22 (twenty two ) perceived quality services aimed at users of PPOB ABSINDO BMT.
\end{abstract}

Keywords : Quality of services, $P P O B$ ABSINDO, Cartesian diagram

\section{PENDAHULUAN}

PPOB ABSINDO adalah sub web dari Absindodiy.net, Beberapa manfaat PPOB ABSINDO terhadap BMT pengguna PPOB ABSINDO adalah bahwa PPOB ABSINDO selain berfungsi sebagai sistem pembayaran payment point online bank, PPOB ini mampu menjadi sumber informasi kegiatan ke- BMT an dengan menampilkan informasi kegiatan ke BMT an pada tampilan yang ada di PPOB ABSINDO dalam bentuk running text dan support web yang ada.(Absindodiy.net). Pada running text yang ada di PPOB ABSINDO terdapat informasi tentang kegiatan tentang ke BMT an dan kegiatan tentang ekonomi syariah, sedangkan pada web absindodiy.net, selain sebagai pintu masuk ke PPOB ABSINDO, web ini juga berisi tentang rangkaian berita dan informasi seputar ekonomi syariah.

PPOB ABSINDO saat ini telah berjalan lebih dari selama 3 (tiga) tahun. Selama jangka waktu ini pula telah terdapat berbagai dinamika baik secara system maupun hubungan emosional antara pengelola web dengan pengelola loket maupun pengguna informasi dari absindodiy.net. Sampai saat ini telah bergabung sebanyak lebih dari 50 loket mitra BMT yang menggunakan PPOB ABSINDO sebagai sebuah sistem PPOB untuk melakukan transaksi PPOB di BMT pengguna PPOB ABSINDO. Langkah kecil telah dimulai, walaupun PPOB ini merupakan co branding dari PPOB Nusantara namun dengan kerja sama sinergis dan support dari PPOB Nusantara, serta kesadaran dari BMT anggota ABSINDO untuk melakukan transaksi pelayanan $P P O B$ nya dengan PPOB ABSINDO, diharapkan PPOB ABSINDO mampu melayani kebutuhan anggota dan mitra BMT dalam berbagai macam transaksi pembayaran diantaranya :

- transaksi pembayaran PLN

- transaksi pembayaran telephon

- Transaksi pulsa

- Transaksi tiket pesawat dan kereta api

- Transaksi BPJS Tenaga Kerja

- Transaksi pembayaran PDAM di beberapa daerah

- Berbagai transaksi lainnya 
Beberapa transaksi tersebut diharapkan dapat dilakukan dengan baik dan lebih bisa memuaskan stakeholder yang ada, kedepan dengan dukungan berbagai pihak diharapkan PPOB ABSINDO mampu melakukan transaksi yang dapat menghubungkan kegiatan antar BMT seperti BMT Checking (SistemInformasi Anggota Pembiayaan) dan atau transaksi lainnya seperti Pembayaran PBB dan kebutuhan jasa pelayanan PPOB anggota dan mitra lainnya.

Ada beberapa kendala ataupun terdapat beberapa kelemahan yang muncul pada sistem PPOB ABSINDO. PPOB ABSINDO adalah sebuah sistem PPOB yang ber basis web, kelemahan dari sistem ini adalah selain membutuhkan hardware dan koneksi internet yang reliable, pada sistem PPOB ABSINDO memerlukan sistem printer yang agak rumit, walaupun hal ini sudah dilakukan maintenance dengan adanya server 3 dari absindodiy.net.Diperlukan pemahaman dasar tentang optimalisasi sistem printernya, sehingga mampu mengurai kerumitan yang dihadapi oleh mitra. Harapannya adalah PPOB ABSINDO akan lebih mudah di install dan digunakan secara mudah dan menjadi PPOB yang lebih sempurna dengan didukung oleh Support Chating dari Bakoel Corporation selaku pemilik co branding dari PPOB ABSINDO.

\section{Rumusan Masalah}

Kepuasan pelanggan total tidak mungkin tercapai, sekalipun hanya sementara waktu (Muddie \& Cottam, 1993). Namun upaya perbaikan atau penyempurnaan kepuasan dapat dilakukan dengan berbagai strategi. Salah satu strategi yang bisa dilakukan adalah evaluasi kualitas pelayanan jasa. Pada PPOB ABSINDO, dengan mengetahui apakah terdapat perbedaan atau gap kualitas jasa pelayanan yang diharapkan oleh BMT pengguna PPOB ABSINDO dan yang selama ini dipersepsikan oleh BMT pengguna PPOB ABSINDO atas kualitas jasa pelayanan yang diterima, akan dapat diketahui pula tindakan evaluasi untuk meningkatkan kualitas jasa pelayanan. Dari uraian tersebut, dapat dirumuskan masalah yaitu
1. Apakah terdapat perbedaan antara harapan dengan kenyataan yang diterima pada penggunaan PPOB ABSINDO

2. Dimensi apa saja yang mempengaruhi harapan dan kenyataan pada penggunaan PPOB ABSINDO

3. Kebijakan apa saja yang dapat di lakukan untuk memperbaiki kualitas jasa pelayanan PPOB ABSINDO

\section{LANDASAN TEORI}

Penelitian mengenai kualitas pelayanan sudah banyak dilakukan. Parasuraman et. al.(1988) melalui riset eksploratorinya, memaparkan kualitas pelayanan dan faktor faktor yang menentukannya. Dalam riset eksploratori tersebut, Parasuraman mendefinisikan kualitas pelayanan sebagai bentuk sikap, terkait tetapi tidak sama dengan kepuasan, yang diperoleh dengan membandingkan antara harapan dengan kinerja yang diterima. Hasil riset ini adalah instrumen SERVQUAL, yaitu suatu skala untuk mengukur kualitas pelayanan yang tercakup dalam lima dimensi yaitu reliability (keandalan), responsiveness (daya tanggap), assurance (jaminan), emphaty (empati) dan tangibles (fasilitas fisik), dan selanjutnya dianalisis dengan analisis gap.

\section{Persepsi Tentang $P P O B$ ABSINDO}

Persepsi pengguna $P P O B$ ABSINDO adalah bagaimana kesan yang ada ketika mulai mengoperasionalkan $P P O B$ ABSINDO kepada BMT pengguna $P P O B$ ABSINDO, persepsi yang digunakan adalah persepsi tentang kualitas jasa pelayanan sistem $P P O B$ ABSINDO untuk melakukan transaksi $P P O B$ di BMT pengguna $P P O B$ ABSINDO. Pertanyaan yang digunakan mengenai kualitas jasa pelayanan adalah tentang kualitas jasa pelayanan yang diharapkan serta kualitas jasa pelayanan yang dirasakan.

Absindodiy.net, adalah website pendukung dari PPOB ABSINDO untuk memberikan informasi kegiatan ke BMT an, termasuk didalamnya untuk membuka aplikasi system PPOB ABSINDO. PPOB ABSINDO adalah sistem $P P O B$ yang didalamnya juga menyediakan pelayanan payment online dengan fitur yang akan terus dikembangkan untuk 
memenuhi kebutuhan pasar, khususnya kepada loket mitra BMT. Melalui $P P O B$ ABSINDO yang merupakan co branding dari $P P O B$ NUSANTARA dengan dukungan dari Bakoel Corporation, dengan menggunakan system PPOB ABSINDO, BMT anggota ABSINDO bisa senantiasa terus melayani mitra dan pelanggannya untuk pembayaran tagihan PLN, Token pre paid PLN, tagihan TELKOM, pembelian pulsa elektrik untuk seluler dan reservasi tiket pesawat untuk maskapai penerbangan domestik, reservasi tiket kereta api, leasing dan multi payment lainnya. Harapan kedepannya dengan menggunakan web system BMT pengguna $P P O B$ ABSINDO tidak perlu repot untuk menginstall aplikasi di komputernya, sehingga jika terjadi masalah maka data transaksi aman asal tersedia komputer lain dengan jaringan internet yang ada di loket mitra yang ada. (www.PPOBnusantara.com)

\section{Persepsi BMT Pengguna $P P O B$ ABSINDO}

Cronin dan Taylor (1992) mengartikan persepsi terhadap kualitas jasa sebagai kinerja (performance). Kinerja dipahami sebagai kinerja yang dipersepsikan, bukan kinerja aktualnya (Bareson, 1995). Parasuraman et. al (1985) menyatakan bahwa pendekatan yang cocok untuk menilai kualitas jasa perusahaan adalah mengukur persepsi konsumen terhadap kualitas. Mereka memdefinisikan persepsi sebagai keyakinan pelanggan mengenai jasa yang diterima (service received) atau jasa yang dialami (experienced service) (Brown and Swartz, 1989).berkenaan dengan fasilitas fisik yang mendukung kualitas jasa. Sedangkan dimensi ketiga adalah corporate quality yang melibatkan image perusahaan.

Persepsi penggunaan $P P O B$ dalam hal ini adalah bagaimana persepsi BMT pengguna $P P O B$ ABSINDO dalam menyelenggarakan $P P O B$ ABSINDO dalam melayani transaksi pembayaran $P P O B$ kepada anggota dan mitra dengan menggunakan system PPOB ABSINDO.

\section{Konsep Gap (Kesenjangan) Kepuasan Pelanggan)}

Menurut Parasuraman (1985), perbedaan cara penyampaian dari apa yang dipersepsikan pelanggan, mencakup lima perbedaan (gap), yaitu :

Gap 1 : Gap antara harapan pelanggan dan persepsi manajemen : tidak mengetahui apa yang diharapkan konsumen

Gap 2 : Gap antara persepsi manajemen tentang harapan pelanggan dan spesifikasi kualitas jasa: tidak memiliki desain dan standar pelayanan yang tepat

Gap 3: Gap antara spesifikasi kualitas jasa dan jasa yang disajikan: tidak memberikan pelayanan sesuai standar pelayanan

Gap 4 : Gap antara penyampaian jasa aktual dan komunikasi eksternal kepada pelanggan: tidak memberikan pelayanan sesuai dengan yang dijanjikan/standar

Gap 5: Gap antara jasa yang diharapkan dan jasa aktual yang diterima pelanggan: perbedaan persepsi konsumen dengan harapan konsumen

Sebagai sebuah lembaga keuangan mikro syariah, BMT akan berupaya semaksimal mungkin untuk memenuhi kebutuhan dari anggotanya, salah satunya adalah melalui optimalisasi jasa pelayanannya dengan memfungsikan kantor pelayanan BMT menjadi loket pembayaran PPOB (Payment Point). Dengan adanya pelayanan $P P O B$ di BMT maka anggota mempunyai harapan atas kualitas jasa yang diberikan oleh BMT, demikian pula BMT penyedia jasa $P P O B$, khususnya BMT pengguna $P P O B$ ABSINDO, mereka juga mempunyai harapan atas kualitas jasa dari $P P O B$ ABSINDO untuk melayani anggotanya.

\section{Pengembangan dan Perumusan Hipotesis}

Kepuasan konsumen akan terpenuhi apabila proses penyampaian jasa dari si penyedia jasa kepada pelanggan sesuai dengan apa yang di persepsikan pelanggan. Oleh karena itu beberapa faktor, seperti subyektifitas yang dipersepsikan pelanggan. Maka jasa sering disampaikan dengan cara yang berbeda dengan yang dipersepsikan oleh pelanggan. Hal ini juga yang terjadi pada penggunaan $P P O B$ ABSINDO, karena sebagian besar mitra memiliki fasilitas yang berbeda-beda dalam memenuhi kebutuhan pelanggan, sehingga hal tersebut berdampak pada timbulnya kesenjangan antara harapan end user dan persepsi mitra. 
Pada penjelasan sebelumnya disebutkan bahwa dimensi kualitas jasa akan berbeda tergantung pada jenis usaha jasa yang akan dinilai. Pada penelitian ini akan diteliti tentang kualitas pelayanan $P P O B$ ABSINDO di loket $P P O B$ di setiap BMT anggota ABSINDO. Penelitian ini mengklasifikasikan BMT berdasarkan jaringan online yang dipakai BMT pengguna, serta berapa lama BMT pengguna menggunakan sistem $P P O B$ ABSINDO dalam melayani transaksi payment point online bank.

\section{Pengujian Hipotesis}

Penelitian ini melakukan pengujian hipotesis yaitu menguji perbedaan antara harapan dan kenyataan kualitas jasa $P P O B$ ABSINDO yang akan dipergunakan oleh BMT tentang system operasional $P P O B$ ABSINDO. Setelah melakukan pengujian hipotesis yang dilakukan adalah menghitung selisih gap antara harapan dan kenyataan yang diperoleh oleh BMT pengguna PPOB ABSINDO.

\section{Diagram Kartesius Untuk Analisis Servqual}

Analisis Servqual (Service and Quality) bisa juga menggunakan Diagram kartesius untuk melakukan analisa. Pada diagram kartesius terdapat 4 kuadran yang berbeda tergantung pada seberapa tinggi dan atau rendahnya persepsi gap atas harapan berbanding dengan kenyataan yang ada. Pertemuan dua sumbu $\mathrm{X}$ dan $\mathrm{Y}$ pada diagram kartesius mempunyai arti sebagai berikut

\section{pengguna}

Sumbu $\mathrm{X}$ adalah harapan BMT

Sumbu Y adalah kenyataan pada pelaksanaan PPOB ABSINDO.

1. Kuadran $A$ untuk nilai $X$ tinggi dan nilai $Y$ rendah yang artinya adalah bahwa BMT pengguna mempunyai harapan yang tinggi dibandingkan dengan kenyataan dari kinerja POB ABSINDO. Kuadran ini adalah prioritas utama untuk meingkatkan kualitas pelayanan PPOB ABSINDO.

2. Kuadran $B$ untuk nilai $X$ tinggi dan nilai $Y$ tinggi yang artinya bahwa harapan BMT pengguna sama dengan kenyataan bahwa kualitas jasa pelayanan PPOB ABSINDO mampu memenuhi harapan BMT pengguna. Kuadran ini adalah kuadran untuk terus mempertahankan kualitas jasa pelayanan PPOB ABSINDO

3. Kuadran $\mathrm{C}$ untuk nilai $\mathrm{X}$ rendah dan nilai $\mathrm{Y}$ rendah yang artinya bahwa baik harapan BMT pengguna maupun kualitas jasa pelayanan PPOB ABSINDO adalah sama rendahnya. Pada kuadran inimerupakan prioritas sistem PPOB ABSINDO untuk ditingkatkan kualitas dan jasa pelayanannya

4. Kuadran $D$ untuk nilai $X$ rendah dan nilai $Y$ tinggi yang artinya bahwa harapan BMT pengguna rendah dan sistem PPOB ABSINDO lebih dari cukup untuk memenuhi harapan BMT pengguna. Kuadran ini bisa dikesampingkan karena sistem PPOB ABSINDO sudah lebih (berlebihan) dalam memenuhi harapan BMT pengguna. 
Gambar 1 Diagram Kartesius :

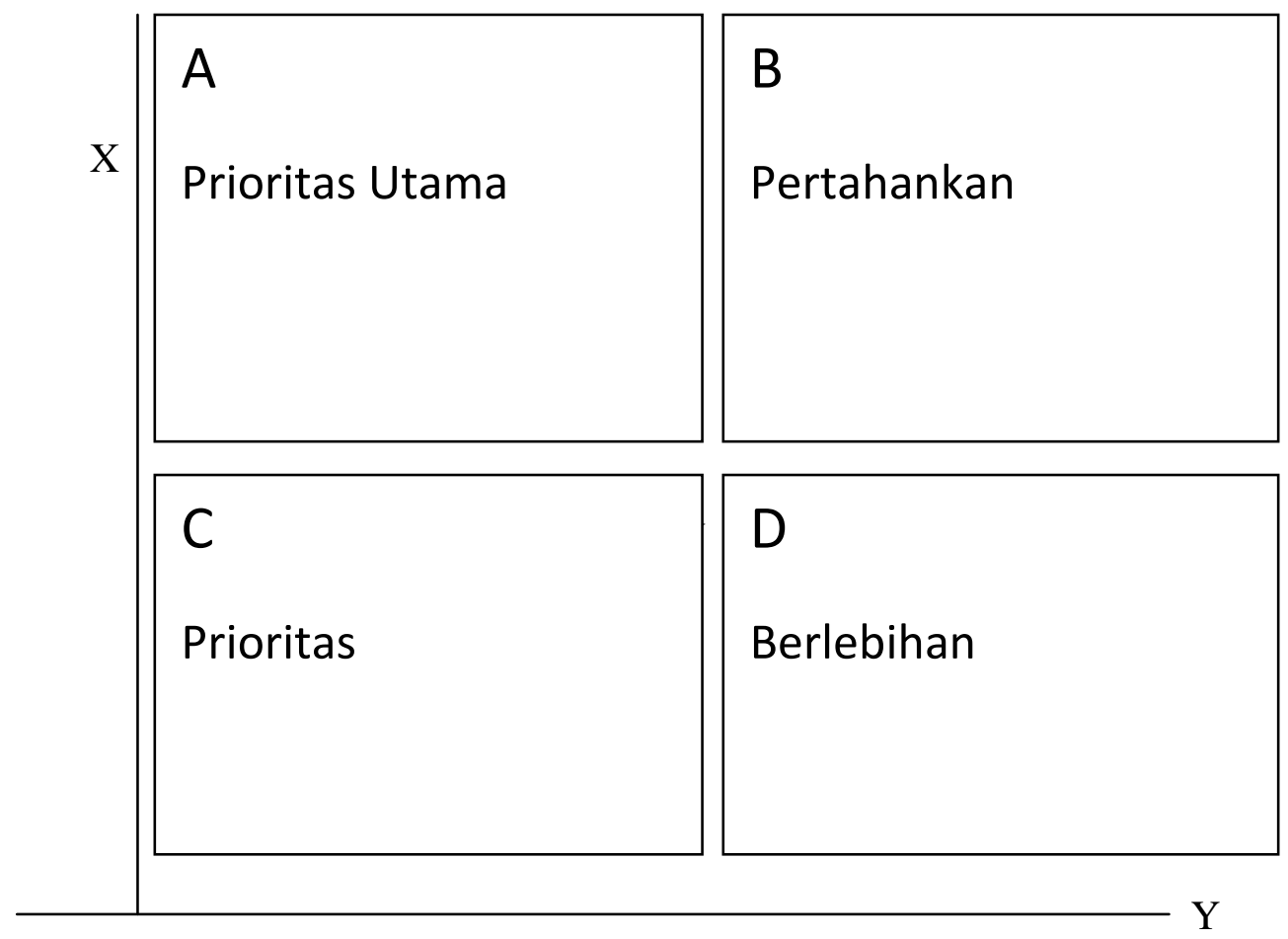

Gambar Kuadran pada Diagram Kartesius

Sebagai catatan ada kemungkinan persepsi penggunaan $P P O B$ ABSINDO akan dipengaruhi oleh masalah jaringan online yang digunakan BMT pengguna $P P O B$ ABSINDO dan jangka waktu (seberapa lama) BMT pengguna $P P O B$ ABSINDO menggunakan system $P P O B$ ABSINDO, sehingga dalam kuesioner yang dibagikan kepada BMT pengguna $P P O B$ ABSINDO disebutkan jaringan online yang dipergunakan dan berapa lama BMT tersebut menggunakan $P P O B$ ABSINDO, namun karena keterbatasan populasi yang ada maka peneliti belum bisa menggunakan perbandingan tersebut.

\section{METODOLOGI PENELITIAN \\ Data yang Diperlukan \\ Data Primer}

Data primer merupakan data yang di dapat dari sumber yang asli dan dikumpulkan secara khusus untuk menjawab pertanyaan penelitian, seperti hasil wawancara atau hasil pengisian kuesioner. Data primer dalam penelitian ini diperoleh dari BMT pengguna PPOB ABSINDO. Data kuesioner berisi persepsi tentang kualitas jasa pelayanan secara umum PPOB ABSINDO yang digunakan oleh BMT pengguna PPOB ABSINDO.

\section{Data Sekunder}

Data sekunder merupakan data yang berasal dari pihak lain dalam bentuk yang sudah jadi. Data-data tersebut berasal dari PPOB client dari PPOB Nusantara yang dapat menampilkan jumlah transaksi dan keterangan tentang penggunaan layanan PPOB ABSINDO oleh BMT pengguna PPOB ABSINDO.

\section{Pemilihan Sampel Penelitian}

PPOB ABSINDO baru beroperasional hampir 2 (dua) tahun ini. Populasi dalam penelitian ini adalah sebagian besar dari BMT pengguna PPOB ABSINDO di wilayah Kota Jogja, Kabupaten Bantul dan Kabupaten Sleman. Pada kuesioner yang dibagikan, untuk lebih bisa menjabarkan potensi dari BMT pengguna, disebutkan juga berapa lama penggunaan PPOB ABSINDO oleh loket BMT pengguna $\mathrm{PPOB}$ ABSINDO dan jaringan internet yang dipergunakan oleh loket PPOB BMT pengguna (Speedy, Wifi atau modem).

Prosedur pengambilan sampel dilakukan dengan cara purposive sampling dan 
convenience sampling. Purposive sampling merupakan pengambilan sampel yang disesuaikan dengan tujuan penelitian, sedangkan convenience sampling adalah pemilihan anggota sampel berdasarkan responden yang mudah ditemui atau dimintai informasi. Sampel pada penelitian ini adalah sebagai berikut :

\begin{tabular}{|c|c|c|c|c|c|c|c|}
\hline \multirow[t]{2}{*}{ NO } & \multirow[t]{2}{*}{ NAMA BMT } & \multicolumn{3}{|c|}{$\begin{array}{l}\text { JARINGAN } \\
\text { ONLINE }\end{array}$} & \multicolumn{3}{|c|}{$\begin{array}{c}\text { LAMA } \\
\text { PENGGUNAAN }\end{array}$} \\
\hline & & $\mathbf{S}$ & $\mathbf{W}$ & $\mathbf{M}$ & $<6$ & $>6$ & $>12$ \\
\hline 1 & BIF GAMPING & & & $\sqrt{ }$ & & $\sqrt{ }$ & \\
\hline 2 & MITRAMA & $\sqrt{ }$ & & & & & $\sqrt{ }$ \\
\hline 3 & BIF SLEMAN & $\sqrt{ }$ & & & & $\sqrt{ }$ & \\
\hline 4 & PRIMA ARTHA & $\sqrt{ }$ & & & $\sqrt{ }$ & & \\
\hline 5 & AZZAM & & & $\sqrt{ }$ & & & $\sqrt{ }$ \\
\hline 6 & SUBULUSSALAM & $\sqrt{ }$ & & & & & $\sqrt{ }$ \\
\hline 7 & AL MUTHIIN & $\sqrt{ }$ & & & & & $\sqrt{ }$ \\
\hline 8 & AS - SALAM & $\sqrt{ }$ & & & & & $\sqrt{ }$ \\
\hline 9 & AGAWE MAKMUR & $\sqrt{ }$ & & & & & $\sqrt{ }$ \\
\hline 10 & ARTHA SEJAHTERA & $\sqrt{ }$ & & & & $\sqrt{ }$ & \\
\hline 11 & TIRTA USAHA MULIA & & & $\sqrt{ }$ & $\sqrt{ }$ & & \\
\hline 12 & KOTAGEDE & & $\sqrt{ }$ & & & & $\sqrt{ }$ \\
\hline 13 & INSAN SADAR USAHA & & & $\sqrt{ }$ & & & $\sqrt{ }$ \\
\hline 14 & DANA INSANI BANTUL & $\sqrt{ }$ & & & & & $\sqrt{ }$ \\
\hline 15 & ARTHA MAKMUR & & & $\sqrt{ }$ & & $\sqrt{ }$ & \\
\hline 16 & SEHATI & & $\sqrt{ }$ & & & & $\sqrt{ }$ \\
\hline 17 & AD’DAKWAH & $\sqrt{ }$ & & & & & $\sqrt{ }$ \\
\hline 18 & PAS (PROJO ARTHA SEJAHTERA) & $\sqrt{ }$ & & & & & $\sqrt{ }$ \\
\hline 19 & ARTHA AMANAH & $\sqrt{ }$ & & & & & $\sqrt{ }$ \\
\hline 20 & ARTHA BAROKAH & $\sqrt{ }$ & & & & & $\sqrt{ }$ \\
\hline 21 & RIZQI BAROKAH & & $\sqrt{ }$ & & $\sqrt{ }$ & & \\
\hline 22 & MATAHARI & & $\sqrt{ }$ & & & & $\sqrt{ }$ \\
\hline 23 & HANIVA & $\sqrt{ }$ & & & & & $\sqrt{ }$ \\
\hline 24 & BANGUNTAPAN & & & $\sqrt{ }$ & $\sqrt{ }$ & & \\
\hline 25 & MABRUR & & & $\sqrt{ }$ & & & $\sqrt{ }$ \\
\hline 26 & SABILUL MUHTADIN & & $\sqrt{ }$ & & & & $\sqrt{ }$ \\
\hline 27 & KOPTAN TANI BAROKAH & $\sqrt{ }$ & & & & & $\sqrt{ }$ \\
\hline 28 & UMY & $\sqrt{ }$ & & & & & $\sqrt{ }$ \\
\hline 29 & SURYA UMBULHARJO & & & $\sqrt{ }$ & & & $\sqrt{ }$ \\
\hline 30 & SURYA BABADAN SEJAHTERA & & & $\sqrt{ }$ & $\sqrt{ }$ & & \\
\hline
\end{tabular}

\section{Pengumpulan dan Pengukuran Data}

Data untuk penelitian ini dikumpulkan melalui kuesioner yang disebarkan kepada BMT pengguna PPOB ABSINDO secara acak. Kuesioner merupakan suatu cara pengumpulan data dengan memberikan atau menyebarkan daftar pertanyaan kepada responden, dengan harapan mereka akan memberikan respon atas daftar pertanyaan tersebut. Kuesioner yang digunakan dalam penelitian ini adalah kuesioner yang berkaitan dengan kualitas pelayanan jasa pada system PPOB ABSINDO yang digunakan oleh BMT pengguna PPOB ABSINDO dengan mengambil sampel sejumlah 22 buah pertanyaan.

Daftar pertanyaan pada kuesioner ini bersifat terbuka dengan metoda pengukuran skala Likert. Peneliti menghilangkan alternatif netral karena untuk menghilangkan keraguraguan responden dalam menjawab pertanyaan 
dan peneliti menginginkan alternatife pilihan yang pasti. Penyebaran kuesioner dilakukan dengan cara mengunjungi secara langsung BMT pengguna PPOB ABSINDO yang dijadikan sampel. Penyebaran kuesioner dilakukan di ruangan kantor pelayanan BMT pengguna PPOB ABSINDO, sehingga semua kuesioner langsung dikembalikan setelah di isi, sehingga tingkat kembalian kuesioner pada penelitian ini sebesar $100 \%$.

Pertanyaan Kuesioner terbagi menjadi 2 (dua) bagian, bagian pertama merupakan kuesioner yang ditujukan kepada BMT pengguna PPOB ABSINDO sebagai cerminan harapan mereka terhadap kualitas jasa pelayanan PPOB ABSINDO. Kuesioner ini terdiri dari 4 (empat) alternative jawaban, yaitu sangat penting(nilai 4), penting (nilai 3), tidak penting (nilai 2) dan sangat tidak penting (nilai 1). Kuesioner bagian kedua merupakan kuesioner yang ditujukan kepada BMT pengguna PPOB ABSINDO yang berisi tentang kinerja jasa yang telah mereka alami atau rasakan. Kuesioner ini terdiri dari 4 (empat) alternatif jawaban, yaitu Sangat setuju (nilai 4), setuju (nilai 3) tidak setuju (nilai 2) dan sangat tidak setuju (nilai 1). Dari 30 kuesioner yang diisi oleh oleh BMT pengguna PPOB ABSINDO di wilayah Kota Jogja, Kabupaten Bantul, dan Kabupaten Sleman dari 51 BMT pengguna PPOB ABSINDO di wilayah DIY dan 2 BMT pengguna di Kalimantan. Dari 30 kuesioner tersebut, semuanya dikembalikan secara lengkap

\section{Variabel atau Dimensi Penelitian}

Variabel atau dimensi yang digunakan dalam penelitian ini adalah dimensi Servqual secara umum meliputi 22 pertanyaan tentang persepsi BMT pengguna yaitu persepsi tentang kualitas jasa pelayanan PPOB ABSINDO secara umum dengan pertanyaan sebagai berikut :

1. Apakah PPOB ABSINDO merupakan PPOB yang lengkap

2. Apakah PPOB ABSINDO merupakan sistem PPOB yang ber basis web

3. Apakah PPOB ABSINDO merupakan PPOB nya insan BMT

4. Apakah PPOB ABSINDO mempunyai fee yang kompetitif
5. Apakah BMT mitra mudah untuk melakukan transaksi

6. Apakah PPOB ABSINDO disupport secara penuh oleh PPOB Nusantara

7. Apakah PPOB ABSINDO bebas masalah

8. Apakah PPOB ABSINDO mempunyai support online chating

9. Apakah PPOB ABSINDO merupakan media informasi bagi ABSINDO

10. Apakah PPOB ABSINDO menjadi sumber informasi kegiatan ke BMT an

11. Apakah PPOB ABSINDO bisa online kapan saja dan dimana saja

12. Apakah PPOB ABSINDO mempunyai fitur yang lengkap dan mudah di pahami

13. Apakah PPOB ABSINDO mempunyai tim tehnis tersendiri

14. Apakah PPOB ABSINDO mudah diakses

15. Apakah PPOB ABSINDO mudah di install

16. Apakah PPOB ABSINDO selalu bertambah fasilitas pelayanannya

17. Apakah BMT mitra mendapatkan fee dengan cepat

18. Apakah BMT mitra mudah melakukan konfirmasi deposit

19. Apakah BMT mitra mendapatkan bimbingan teknis pelayanan PPOB

20. Apakah BMT mitra di ikutkan dalam kegiatan ABSINDO

21. Apakah BMT mitra mendapatkan solusi pada online chating

22. Apakah jika ada masalah selalu di informasikan kepada BMT pengguna PPOB ABSINDO

\section{Metode Analisis Data}

Analisis data didasarkan pada hasil kuesioner yang telah diisi secara lengkap oleh BMT pengguna PPOB ABSINDO. Data yang telah dianalisis akan disampaikan dalam bentuk angka, tabel, analisis statistik, uraian hasil analisis, dan kesimpulan hasil analisis.

\section{Uji Validitas dan Uji Reliabilitas}

Kuesioner disebarkan dan kesemuanya di lakukan uji coba sampel sebanyak 30 responden. Setelah itu lakukan analisis butir terhadap data yang telah diperoleh. Analisis yang dilakukan adalah analisis uji validitas (uji kesahihan) dan uji reliabilitas (uji keandalan) 
terhadap pertanyaan-pertanyaan yang ada di kuesioner.

Uji validitas didefinisikan sebagai tingkat kemampuan suatu instrument (kuesioner) dalam melakukan fungsinya, yaitu kemampuan untuk mengungkap sesuatu yang menjadi sasaran pokok pengukuran (Hadi, 1991). Suatu instrument dikatakan valid bila instrumen tersebut memiliki kemampuan mengukur apa yang seharusnya diukur.

Pengujian validitas ada beberapa macam. Dalam penelitian ini digunakan pengujian validitas konstruk melalui analisis faktor terhadap instrumen. Analisis faktor dilakukan dengan cara mengkorelasikan jumlah skor faktor dengan skor total. Bila korelasi tiap faktor tersebut positif dan besarnya 0,3 ke atas maka faktor tersebut merupakan konstruk yang kuat. Sehingga berdasarkan analisis faktor tersebut, dapat disimpulkan bahwa instrumen memiliki validitas konstruk yang baik.

Uji reliabilitas digunakan untuk menunjukkan tingkat kemantapan dan ketepatan alat ukur, dalam arti apakah ukuran yang diperoleh merupakan ukuran yang benar dari sesuatu yang hendak diukur (Hadi, 1991). Reliabilitas berhubungan dengan konsistensi dan stabilitas suatu skor dari suatu instrumen pengukur. Reliabilitas instrumen dapat diketahui dengan menghitung cronbach's alpha. Instrumen untuk mengukur masing- masing variabel dikatakan reliabel jika memiliki cronbach's alpha lebih besar dari 0,50 (Nunnally, 1967).

Rumus cronbach's alpha digunakan untuk mencari reliabilitas instrumen yang skornya bukan $0-1$, tetapi merupakan rentangan antara beberapa nilai, misalnya 0 10, atau bentuk skala $1-3,1-5$, dan seterusnya. Rumus cronbach's alpha adalah sebagai berikut:

$$
r_{11}=\left(\frac{k}{k-1}\right)\left(1-\frac{\sum \sigma_{b}^{2}}{\sigma_{t}^{2}}\right)
$$

\section{Analisis Gap dengan Menggunakan Instrumen SERVQUAL}

Parasuraman et. al (1988) melalui riset eksploratorinya, memaparkan kualitas pelayanan dan faktor- faktor yang menentukannya. Hasil riset eksploratori tersebut adalah instrumen SERVQUAL (service quality), yaitu suatu skala untuk mengukur kualitas pelayanan yang tercakup dalam lima dimensi yaitu reliability (keandalan), responsiveness (daya tanggap), assurance (jaminan), emphaty (empati) dan tangibles (fasilitas fisik), dan selanjutnya dianalisis dengan analisis gap.

Shank et. al (1995) menggunakan instrumen SERVQUAL yang dikembangkan oleh Parasuraman et. al (1988) untuk mengukur kualitas pelayanan pada lembaga pendidikan tinggi. Berdasarkan dimensi-dimensi yang dikembangkan oleh Parasuraman, Pada penelitian persepsi tentang penggunaan PPOB ABSINDO ini telah diupayakan untuk melalui penghitungan koefisien alpha dan analisis faktor (iteration of computing coeffisient alpha and factor analysis) yang bertujuan untuk menghindari terjadinya overlapping di antara pertanyaan-pertanyaan yang ada dan dimensi/faktor.

Dari sejumlah 22 pertanyaan yang ada, pertanyaan tersebut mencakup dimensi SERVQUAL secara umum yang terbagi kepada 22 (dua puluh dua) persepsi yaitu persepsi tentang kualitas jasa pelayanan $P P O B$ $A B S I N D O$ secara umum. Analisis gap dengan instrumen SERVQUAL dilakukan dengan cara menghitung gap yang terjadi antara harapan BMT pengguna system PPOB ABSINDO dengan penilaian dari pengelola (staff) BMT pengguna PPOB ABSINDO atas kualitas system PPOB ABSINDO yang digunakan oleh BMT pengguna PPOB ABSINDO.

Analisis SERVQUAL ini dapat dilakukan untuk tiap dimensi dan untuk tiap atribut atau pertanyaan (Parasuraman dkk, 1990). Langkah pertama untuk melakukan penilaian kualitas pelayanan jasa yaitu dengan menghitung servqual score dari tiap pasangan pertanyaan yang mewakili harapan dan kenyataan. Servqual score diperoleh dengan pengurangan antara kenyataan dengan harapan.

Untuk menganalisis kualitas pelayanan jasa yang telah diberikan, maka digunakan rumus (Besterfield, 1998), yaitu : 


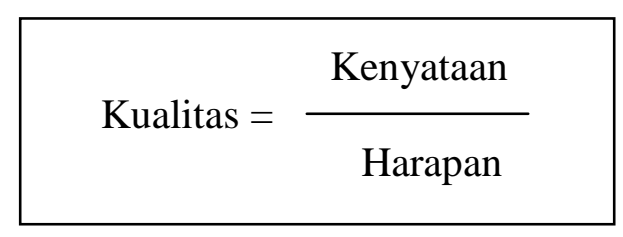

Jika Q (quality) ${ }^{3}$ 1, maka kualitas pelayanan

jasa dikatakan baik

\section{Uji Signifikasi Statistik \\ Paired Sample T-Test}

Uji $\mathrm{t}$ dalam penelitian ini digunakan untuk menguji $\mathrm{H} 1$ Untuk menguji $\mathrm{H} 1$, kuesioner yang telah diisi oleh responden dipisahkan antara harapan BMT pengguna PPOB ABSINDO mengenai kualitas jasa system PPOB ABSINDO dengan kualitas jasa system PPOB ABSINDO yang telah diterima oleh BMT pengguna system PPOB ABSINDO tersebut. Kuesioner yang telah diisi dibedakan menurut harapan dan kenyataan yang diperoleh oleh BMT pengguna PPOB ABSINDO.

Uji ini digunakan untuk menganalisis perbandingan untuk dua sampel yang berpasangan. Dua sampel yang berpasangan diartikan sebagai sebuah sampel dengan subyek yang sama namun mengalami dua perlakuan atau pengukuran yang berbeda. Dua sampel yang digunakan dalam penelitian ini adalah BMT pengguna PPOB ABSINDO, yang mengalami dua perlakuan atau pengukuran. Dua perlakuan atau pengukuran tersebut adalah harapan BMT pengguna system PPOB ABSINDO mengenai kualitas jasa PPOB ABSINDO yang akan diterima dan kenyataan yang diterima oleh BMT pengguna PPOB ABSINDO atas kualitas jasa yang diterima oleh BMT pengguna PPOB ABSINDO, pada dimensi kualitas jasa pelayanan $P P O B$ $A B S I N D O$ secara umum.

\section{Uji t}

Uji $\mathrm{t}$ dalam penelitian ini digunakan untuk menguji $\mathrm{H} 2$. Untuk menguji $\mathrm{H} 2$, kuesioner mengenai harapan BMT pengguna system PPOB ABSINDO atas kualitas dan kesan tentang BMT pengguna PPOB ABSINDO dipisahkan antara BMT pengguna PPOB ABSINDO yang mendapatkan kesan tentang system PPOB ABSINDO dengan BMT pengguna PPOB ABSINDO yang sesungguhnya. Perbedaan mean dihitung untuk masing-masing dimensi, yaitu persepsi tentang persepsi tentang kualitas jasa pelayanan PPOB ABSINDO secara umum (system PPOB ABSINDO secara umum).

\section{Diagram Kartesius untuk analisis Servqual}

Setelah melakukan korelasi butir instrument dan analisa gap antara harapan BMT Pengguna PPOB ABSINDO terhadap kualitas jasa secara umum system PPOB ABSINDO. Berdasarkan nilai yang diperoleh pada servqual score dari tiap pasangan pertanyaan yang mewakili harapan dan kenyataan. Nilai tersebut kemudian di letakkan kepada masing-masing kuadran yang ada pada diagram kartesius. Arti masing-masing kuadran pada Diagram Kartesius adalah sebagai berikut :

Kuadran A.

Menunjukkan faktor atau atribut yang dianggap mempengaruhi kepuasan BT pengguna, termasuk unsur-unsur jasa yang dianggap sangat penting, namun sistem PPOB ABSINDO belum mampu melaksanakannya sesuai keinginan pelanggan.

Kuadran B.

Menunjukkan unsur jasa sistem PPOB yang telah berhasil dilakukan oleh sistem PPOB ABSINDO, untuk itu wajib dipertahankannya. Dianggap sangat penting dan cukup memuaskan, serta harus dipertahankan kinerjanya.

Kuadran C.

Menunjukkan beberapa faktor yang kurang penting pengaruh-nya bagi BMT pengguna, namun pelaksanaan oleh sistem PPOB ABSINDO masih biasa-biasa saja. Hal ini masih dianggap kurang penting dan kurang memuaskan.serta menjadi prioritas yang harus segera dibenahi oleh PPOB ABSINDO

Kuadran D.

Menunjukkan faktor harapan yang mempengaruhi BMT pengguna kurang penting, akan tetapi pelaksanaannya berlebihan. Pada kuadran ini dianggap kurang penting karena pada kenyataannya sistem PPOB ABSINDO mampu memuaskan kebutuhan harapan BMT pengguna. 
HASIL DAN PEMBAHASAN

\section{Uji Asumsi}

Setelah kuesioner disebarkan dan mencapai jumlah tertentu, maka dilakukan analisis butir terhadap data yang telah diperoleh. Analisis yang dilakukan adalah uji validitas (uji kesahihan) dan uji reliabilitas (uji keandalan).

\section{Uji Validitas}

Uji validitas dilakukan untuk mengetahui sejauh mana ketepatan dan kecermatan butir-butir dari alat penelitian (kuesioner) dalam menjalankan fungsinya. Penelitian menggunakan kuesioner dengan isntrumen service quality yang mencakup 22 (dua puluh dua) persepsi mengenai PPOB ABSINDO secara umum. Instrumen tersebut diberikan kepada 30 responden sebagai uji coba sampel untuk menjawabnya. Arti angka 4 adalah sangat sangat setuju, angka 3 adalah setuju,angka 2 adalah tidak setuju, dan angka 1 adalah sangat tidak setuju. Berdasarkan tabel di bawah ini diketahui bahwa korelasi antara jumlah factor X1, X2, X3 sampai dengan X 22 dengan skor total $(\mathrm{Y})$ memiliki koefisien diatas 0,30. Artinya ke dua puluh dua persepsi yaitu merupakan konstruk yang valid untuk mengukur tingkat kepuasan BMT pengguna PPOB ABSINDO atas kualitas jasa dari system PPOB ABSINDO.

Hal ini dapat diketahui dengan cara mengkorelasikan antara skor butir dengan skor total. Dalam penelitian ini terdapat 22 koefisien korelasi yang perlu dihitung. Berdasarkan pengujian validitas, butir-butir pertanyaan dalam kuesioner menunjukkan bahwa skor pertanyaan-pertanyaan yang termasuk dalam persepsi umum tentang PPOB ABSINDO. berikut ini :

Hasilnya ditunjukkan melalui tabel

Tabel 1

Korelasi Butir Instrumen untuk Persepsi Umum PPOB ABSINDO dengan Skor Total

\begin{tabular}{lccc}
\hline NO & r hitung & r kritis & KEPUTUSAN \\
\hline X1Y & 0,303 & 0,30 & Valid \\
X2Y & 0,381 & 0,30 & Valid \\
X3Y & 0,604 & 0,30 & Valid \\
X4Y & 0,335 & 0,30 & Valid \\
X5Y & 0,356 & 0,30 & Valid \\
X6Y & 0,348 & 0,30 & Valid \\
X7Y & 0,374 & 0,30 & Valid \\
X8Y & 0,332 & 0,30 & Valid \\
X9Y & 0,505 & 0,30 & Valid \\
X10Y & 0,527 & 0,30 & Valid \\
X11Y & 0,426 & 0,30 & Valid \\
X12Y & 0,372 & 0,30 & Valid \\
X13Y & 0,370 & 0,30 & Valid \\
X14Y & 0,309 & 0,30 & Valid \\
X15Y & 0,393 & 0,30 & Valid \\
X16Y & 0,369 & 0,30 & Valid \\
X17Y & 0,526 & 0,30 & Valid \\
X18Y & 0,307 & 0,30 & Valid \\
X19Y & 0,676 & 0,30 & Valid \\
X20Y & 0,641 & 0,30 & Valid \\
X21Y & 0,531 & 0,30 & Valid \\
X22Y & 0,607 & 0,30 & Valid
\end{tabular}

Sumber : data primer di olah 
Berdasarkan tabel diatas, dapat diketahui bahwa semua butir pertanyaan ternyata harga korelasi dari butir pertanyaan tersebut lebih besar dari 0,30. Maka semua butir pertanyaan tersebut valid.

\section{Uji Reliabilitas}

Setelah memastikan bahwa kuesioner yang digunakan benar-benar dapat berfungsi sebagai pengumpul data yang akurat dan dapat dipercaya (reliabel), maka perlu dilakukan uji reliabilitas (uji keandalan) butir yang sahih. Reliabilitas berhubungan dengan konsistensi dari nilai yang diperoleh individu yang sama pada waktu yang lain, atau di bawah kondisi variabel penelitian yang lain.

Setelah dihitung dengan menggunakan rumus cronbach's alpha, maka dapat diketahui bahwa reliabilitas dari butir pertanyaan dalam instrumen sebesar 1,034477747. Nilai $\mathrm{r}$ tabel sebesar $\mathrm{n}-1=30-1=29$ sebesar 0,367. Karena $r$ hitung lebih besar dari $r$ tabel, maka kuesioner sebagai alat pengukur dalam penelitian ini telah memenuhi syarat reliabilitas.

Dari hasil tersebut, dapat diketahui bahwa seluruh butir pertanyaan memenuhi uji kesahihan dan uji keandalan. Dari hasil penelitian ini, dapat disimpulkan bahwa kuesioner yang diedarkan benar-benar telah dapat mengukur apa-apa yang hendak diukur dan merupakan alat pengukur yang dapat dipercaya. Dengan terpenuhinya uji asumsi tersebut, maka analisis terhadap data yang diperoleh dapat dilakukan.

\section{Analisis Gap antara Harapan BMT Pengguna PPOB ABSINDO Terhadap Persepsi dimensi kualitas jasa pelayanan system PPOB ABSINDO.}

Analisis SERVQUAL dilakukan dengan cara menghitung gap (perbedaan) yang terjadi antara harapan dan kenyataan yang diterima BMT pengguna PPOB ABSINDO atas kualitas pelayanan jasa secara umum system PPOB ABSINDO. Langkah pertama untuk melakukan penilaian kualitas pelayanan jasa yaitu dengan menghitung servqual score dari tiap pasangan pertanyaan yang mewakili harapan dan kenyataan. Servqual score diperoleh dengan pengurangan antara kenyataan dengan harapan.

Tabel 2

Gap antara Harapan BMT pengguna PPOB ABSINDO

Terhadap Kualitas Jasa system PPOB ABSINDO

\begin{tabular}{lccc}
\hline ITEM & KENYATAAN & HARAPAN & GAP \\
\hline 1 & 2,967 & 3,233 & $-0,266$ \\
2 & 3,300 & 3,333 & $-0,033$ \\
3 & 3,200 & 3,300 & $-0,1$ \\
4 & 3,033 & 3,133 & $-0,1$ \\
5 & 3,033 & 3,300 & $-0,266$ \\
6 & 3,333 & 3,266 & $-0,066$ \\
7 & 2,466 & 2,866 & $-0,4$ \\
8 & 3,300 & 3,466 & $-0,166$ \\
9 & 3,133 & 3,200 & $-0,066$ \\
10 & 3,133 & 3,100 & $-0,033$ \\
11 & 3,333 & 3,433 & $-0,1$ \\
12 & 3,000 & 3,333 & $-0,333$ \\
13 & 3,100 & 3,266 & $-0,166$ \\
14 & 3,100 & 3,366 & $-0,266$ \\
15 & 3,066 & 3,200 & $-0,133$ \\
16 & 2,800 & 3,133 & $-0,333$ \\
17 & 3,033 & 3,200 & $-0,166$ \\
18 & 3,066 & 3,333 & $-0,166$ \\
19 & 3,100 & 3,233 & $-0,133$
\end{tabular}




\begin{tabular}{llll}
20 & 3,166 & 3,266 & $-0,1$ \\
21 & 3,100 & 3,400 & $-0,3$ \\
22 & 3,066 & 3,233 & $-0,166$ \\
\hline
\end{tabular}

Sumber : data primer diolah

Hasil analisis diatas secara umum Berikut ini akan di urutkan gap harapan BMT menunjukkan bahwa harapan BMT pengguna pengguna PPOB ABSINDO atas kualitas PPOB ABSINDO atas kualitas jasa pelayanan pelayanan jasa dengan kualitas pelayanan jasa lebih tinggi dari kualitas jasa pelayanan yang yang telah diterima, dari gap yang paling tinggi telah mereka terima. Hal tersebut ditunjukkan sampai yang paling rendah. Urutan gap tersebut dengan servqual score yang bernilai negative. dapat dilihat secara lengkap pada table berikut:

\section{Tabel 3}

Urutan Besarnya Gap antara Harapan BMT Pengguna PPOB ABSINDO atas Kualitas Pelayanan Jasa dengan Kualitas Pelayanan Jasa yang Telah diterima oleh BMT Pengguna PPOB ABSINDO

\begin{tabular}{|c|c|c|c|}
\hline $\begin{array}{l}\text { Nomor } \\
\text { Urut }\end{array}$ & $\begin{array}{l}\text { Nomor } \\
\text { Item }\end{array}$ & Item & GAP \\
\hline 1 & 2 & $\begin{array}{l}\text { PPOB ABSINDO merupakan system PPOB yang ber } \\
\text { basis web }\end{array}$ & -0.033 \\
\hline 2 & 10 & $\begin{array}{l}\text { PPOB ABSINDO menjadi sumber informasi kegiatan } \\
\text { ke BMT an }\end{array}$ & -0.033 \\
\hline 3 & 12 & $\begin{array}{l}\text { PPOB ABSINDO mempunyai fitur yang lengkap dan } \\
\text { mudah dipahami }\end{array}$ & -0.033 \\
\hline 4 & 6 & $\begin{array}{l}\text { PPOB ABSINDO di support penuh oleh PPOB } \\
\text { Nusantara }\end{array}$ & -0.066 \\
\hline 5 & 9 & $\begin{array}{l}\text { PPOB ABSINDO merupakan media informasi bagi } \\
\text { ABSINDO }\end{array}$ & -0.066 \\
\hline 6 & 3 & PPOB ABSINDO merupakan PPOB nya insan BMT & -0.1 \\
\hline 7 & 4 & PPOB ABSINDO mempunyai fee yang kompetitif & -0.1 \\
\hline 8 & 11 & $\begin{array}{l}\text { PPOB ABSINDO bisa online kapan saja dan dimana } \\
\text { saja }\end{array}$ & -0.1 \\
\hline 9 & 20 & BMT Mitra di ikutkan dalam kegiatan ABSINDO & -0.1 \\
\hline 10 & 15 & PPOB ABSINDO mudah di install & -0.133 \\
\hline 11 & 19 & $\begin{array}{l}\text { BMT Mitra mendapatkan bimbingan teknis pelayanan } \\
\text { PPOB }\end{array}$ & -0.133 \\
\hline 12 & 8 & PPOB ABSINDO mempunyai support online chating & -0.166 \\
\hline 13 & 13 & PPOB ABSINDO mempunyai tim tehnis tersendiri & -0.166 \\
\hline 14 & 17 & BMT Mitra mendapatkan fee dengan cepat & -0.166 \\
\hline 15 & 18 & BMT Mitra mudah melakukan konfirmasi deposit & -0.166 \\
\hline 16 & 22 & $\begin{array}{l}\text { Jika ada masalah selalu di informasikan kepada loket } \\
\text { mitra }\end{array}$ & -0.166 \\
\hline 17 & 1 & PPOB ABSINDO merupakan PPOB yang lengkap & -0.266 \\
\hline 18 & 5 & BMT mitra mudah melakukan transaksi & -0.266 \\
\hline 19 & 14 & PPOB ABSINDO mudah diakses & -0.266 \\
\hline 20 & 21 & BMT Mitra mendapatkan solusi pada online chating & -0.3 \\
\hline
\end{tabular}




\begin{tabular}{crrr}
21 & 16 & $\begin{array}{l}\text { PPOB ABSINDO selalu bertambah fasilitas } \\
\text { pelayanannya }\end{array}$ \\
22 & $7 \quad$ PPOB ABSINDO bebas masalah & -0.333 \\
& Sumber : data primer diolah & -0.4 \\
\hline
\end{tabular}

Dari persepsi Umum tentang kualitas jasa pelayanan PPOB ABSINDO, kemudaian diambil mean dan gap dari setiap persepsi. Hasil perhitungan tersebut dapat dilihat pada tabel berikut :

\section{Tabel 4}

Kualitas Jasa Pelayanan Yang diterima, diharapkan, dan Gap Kualitas Jasa Pelayanan per Persepsi pada sistem PPOB ABSINDO

\begin{tabular}{llll}
\hline PERSEPSI & KENYATAAN & HARAPAN & GAP \\
\hline PPOB ABSNDO & 18.866 & 19.566 & -0.700 \\
SCR UMUM & & & \\
MEAN & 22,610 & 23,870 & $-1,260$ \\
\hline Sumber $\cdot$ data primer diolah & &
\end{tabular}

Tabel tersebut di atas memerlihatkan bahwa skor untuk harapan 23,870 lebih tinggi dibandingkan skor untuk kenyataan 22,610, dan terjadi gap karena servqual score bernilai negative -1,260 Skor ini menunjukkan bahwa kualitas jasa pelayanan yang diberikan oleh
PPOB ABSINDO belum memenuhi harapan BMT pengguna PPOB ABSINDO.

Berdasarkan skor harapan dan kenyataan yang telah diperoleh untuk setiap persepsi, maka penggolongan kualitas pelayanan jasa untuk setiap persepsi dapat dilihat pada tabel berikut ini :

Tabel 5

Kualitas Jasa Pelayanan PPOB ABSINDO

Pada system PPOB ABSINDO

\begin{tabular}{|c|c|c|c|}
\hline PERSEPSI & $\begin{array}{c}\text { SKOR } \\
\text { KENYATAAN }(\mathrm{P})\end{array}$ & $\begin{array}{c}\text { SKOR } \\
\text { HARAPAN (E) }\end{array}$ & $\mathrm{Q}=\mathrm{P} / \mathrm{E}$ \\
\hline PPOB sec & 18,866 & 19,566 & 0,964 \\
\hline Mean & 22,610 & 23,800 & 0,950 \\
\hline
\end{tabular}

Sumber; data primer di olah

Berdasarkan hasil yang diperoleh diatas, maka secara keseluruhan kualitas jasa pelayanan yang diberikan oleh system PPOB ABSINDO belum memenuhi harapan BMTpengguna PPOB ABSINDO. Hal tersebut ditunjukan dengan nilai $\mathrm{Q}=0,950(\mathrm{Q} \leq 1)$.

Uji Beda Antara Harapan Mengenai Kualitas Jasa Pelayanan yang Akan Diterima oleh BMT Pengguna PPOB ABSINDO dengan

\section{Kualitas Jasa Pelayanan yang diterima BMT Pengguna PPOB ABSINDO}

Hipotesis diatas menyatakan bahwa harapan mengenai kualitas jasa pelayanan yang akan diterima oleh BMT pengguna PPOB ABSINDO berbeda dengan kualitas jasa pelayanan yang diterima oleh BMT pengguna PPOB ABSINDO, untuk tiap-tiap persepsi kualitas jasa pelayanan yang ada. Hipotesis ini diuji dengan menggunakan Paired Sample Ttest. Hasilnya ditunjukkan pada tabel berikut : 


\section{Tabel 6}

Hasil T-test Perbedaan Mean antara Kualitas Jasa Pelayanan yang diterima dengan Harapan BMT Pengguna PPOB ABSINDO atas kualitas jasa pelayanan yang ada (untuk tiap-tiap persepsi kualitas jasa pelayanan)

\begin{tabular}{cccccc}
\hline Persepsi & $\begin{array}{c}\text { Mean } \\
\text { Dan SD }\end{array}$ & Kenyataan & Harapan & t-hitung & t-tabel \\
\hline PPOB & Mean & 18,866 & 19,566 & 2,022 & 1,96 \\
$\begin{array}{c}\text { ABSINDO } \\
\text { Secara }\end{array}$ & SD & 2,177 & 2,238 & & \\
Umum & & & & & \\
\hline
\end{tabular}

Sumber : data primer, di olah

Tabel 6 menunjukkan bahwa :

untuk persepsi PPOB secara umum diperoleh hasil $\mathrm{t}$ hitung $=2,022>\mathrm{t}$-tabel 1,96 , yang artinya ada perbedaan antara mean kualitas jasa pendidikan yang diterima dengan harapan BMT pengguna PPOB ABSINDO atas kualitas jasa pelayanan pada sistem PPOB ABSINDO. Hasil ini menunjukkan bahwa $\mathrm{H} 1$ ditolak

\section{Diagram Kartesius untuk Analisis Servqual Kualitas Jasa Pelayanan PPOB ABSINDO}

Analisis Servqual dapat juga dilakukan dengan pemisahan kuadran yang membedakan antara harapan dengan kenyataan atas kualitas jasa pelayanan PPOB ABSINDO oleh BMT pengguna yang dapat dilihat pada table berikut ini :

Tabel 7

Pemisahan Kuadran analisa servqual pada Diagram Kartesius

\begin{tabular}{|c|c|c|c|c|}
\hline \multirow{2}{*}{ No } & \multirow{2}{*}{ Item } & \multicolumn{2}{|c|}{ Nilai rata - rata } & \multirow{2}{*}{ Kuadran } \\
\hline & & Realitas & Harapan & \\
\hline 1 & PPOB ABSINDO merupakan PPOB yang lengkap & 2,967 & 3,233 & B \\
\hline 2 & $\begin{array}{l}\text { PPOB ABSINDO merupakan system PPOB yang } \\
\text { ber basis web }\end{array}$ & 3,300 & 3,333 & B \\
\hline 3 & PPOB ABSINDO merupakan PPOB nya insan BMT & 3,200 & 3,300 & B \\
\hline 4 & PPOB ABSINDO mempunyai fee yang kompetitif & 3,033 & 3,133 & D \\
\hline 5 & BMT mitra mudah melakukan transaksi & 3,033 & 3,300 & B \\
\hline 6 & $\begin{array}{l}\text { PPOB ABSINDO di support penuh oleh PPOB } \\
\text { Nusantara }\end{array}$ & 3,033 & 3,266 & B \\
\hline 7 & PPOB ABSINDO bebas masalah & 2,466 & 2,866 & C \\
\hline 8 & $\begin{array}{l}\text { PPOB ABSINDO mempunyai support online } \\
\text { chating }\end{array}$ & 3,300 & 3,466 & B \\
\hline 9 & $\begin{array}{l}\text { PPOB ABSINDO merupakan media informasi bagi } \\
\text { ABSINDO }\end{array}$ & 3,133 & 3,200 & B \\
\hline 10 & $\begin{array}{l}\text { PPOB ABSINDO menjadi sumber informasi } \\
\text { kegiatan ke BMT an }\end{array}$ & 3,133 & 3,100 & D \\
\hline 11 & $\begin{array}{l}\text { PPOB ABSINDO bisa online kapan saja dan } \\
\text { dimana saja }\end{array}$ & 3,333 & 3,433 & B \\
\hline 12 & $\begin{array}{l}\text { PPOB ABSINDO mempunyai fitur yang lengkap } \\
\text { dan mudah dipahami }\end{array}$ & 3,000 & 3,333 & B \\
\hline 13 & PPOB ABSINDO mempunyai tim tehnis tersendiri & 3,100 & 3,266 & B \\
\hline 14 & PPOB ABSINDO mudah diakses & 3,100 & 3,366 & B \\
\hline 15 & PPOB ABSINDO mudah di install & 3,066 & 3,200 & B \\
\hline 16 & PPOB ABSINDO selalu bertambah fasilitas & 2,800 & 3,133 & C \\
\hline
\end{tabular}


JURNAL AKUNTANSI VOL. 3 NO. 2 DESEMBER 2015

pelayanannya

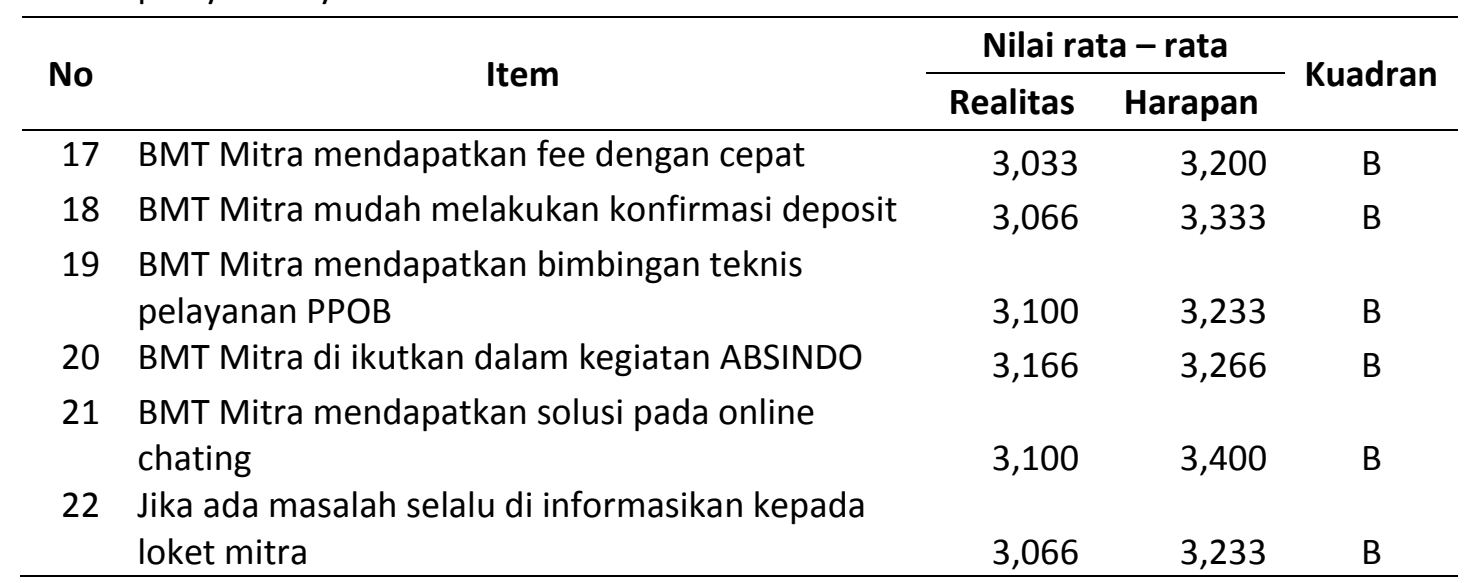

Sumber : data di olah

Tabel 7 menunjukkan bahwa :

Secara umum terdapat 3 kuadran pada persepsi kualitas jasa pelayanan PPOB ABSINDO, yaitu berada pada kuadran $\mathrm{B}$, kuadran $\mathrm{C}$ dan $\mathrm{D}$. Untuk lebih mengetahui posisi per item pada kualitas jasa pelayanan analisa gap antara harapan dengan kenyataan untuk aplikasi PPOB ABSINDO di BMT pengguna dapat digambarkan dengan Diagram Kartesius pada gambar berikut ini :

\section{Gambar 2}

Diagram Kartesius Persepsi PPOB ABSINDO

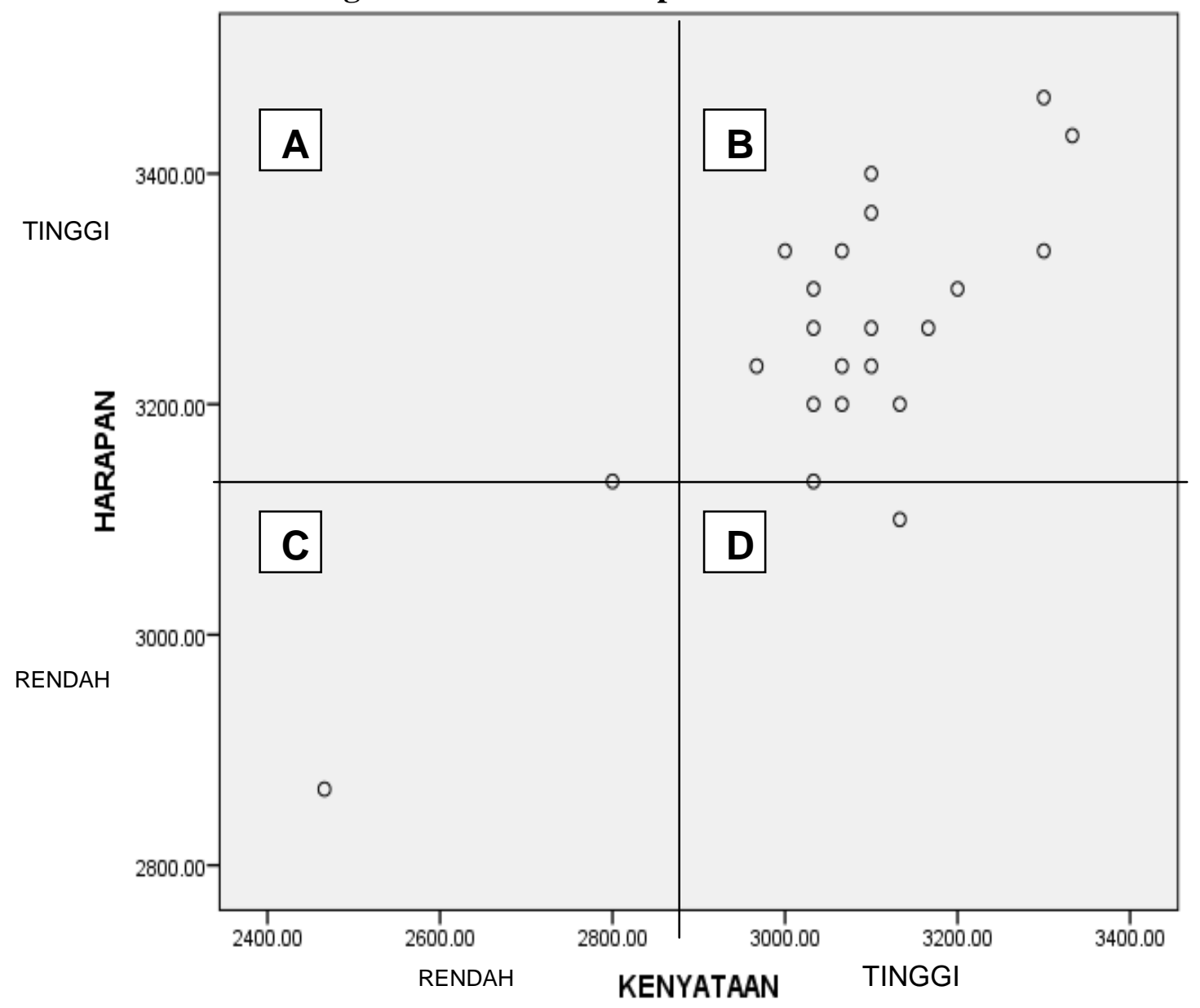

Sumber : data primer di olah 
Gap terjadi karena apa yang menurut persepsi dianggap penting, ternyata bagi BMT Pengguna PPOB hal tersebut dalam pelaksanaannya masih berbeda dengan kenyataan yang ada. Arti Diagram Kartesius pada penelitian ini adalah ;

- Kuadran A, menunjukkan atribut-atribut yang mempengaruhi kepuasan BMT Pengguna PPOB, namun system PPOB ABSINDO belum mampu melaksanakannya dengan baik, pada kuadran ini zero (kosong) yang artinya secara umum PPOB ABSINDO belum mampu memenuhi harapan BMT Pengguna, atau dengan kata lain harapan BMT Pengguna terhadap PPOB ABSINDO sangatlah tinggi sehingga PPOB ABSINDO belum mampu memenuhi harapan BMT pengguna.

- Kuadran B, menunjukkan atribut yang mempengaruhi kepuasan PPOB BMT pengguna PPOB ABSINDO sudah mampu diaplikasikan sesuai dengan harapan BMT Pengguna, antara lain: PPOB ABSINDO merupakan PPOB yang lengkap, PPOB ABSINDO adalah system yang ber basis web, PPOB ABSINDO merupakan PPOB nya Insan BMT, BMT Pengguna mudah melakukan transaksi, PPOB ABSINDO disupport penuh oleh PPOB Nusantara, PPOB ABSINDO mempunyai support onlinechatting, PPOB ABSINDO bisa online kapan saja dan dimana saja, PPOB ABSINDO mempunyai fitur yang lengkap dan mudah dipahami, PPOB ABSINDO mempunyai tim tehnis tersendiri, PPOB ABSINDO mudah diakses, PPOB ABSINDO mudah di install, BMT mitra mendapatkan fee dengan cepat, BMT mitra mudah mendapatkan konfirmasi deposit, BMT mitra mendapatkan bimbingan tehnis pelayanan PPOB, BMT mitra di ikutkan pada kegiatan ABSINDO, BMT mitra mendapatkan solusi pada online chatting, dan jika ada masalah selalu di informasikan kepada BMT pengguna.

- Kuadran C, menunjukkan bahwa atribut yang berada pada kuadran ini, dianggap kurang penting oleh BMT Pengguna. Sedangkan kualitas pelayanan yang diberikan PPOB
ABSINDO tergolong cukup. Atribut-atribut yang termasuk pada kuadran $C$, antara lain: PPOB ABSINDO bebas masalah, dan PPOB ABSINDO selalu bertambah fasilitas pelayanannya.

- Kuadran D, menunjukkan bahwa atribut yang berada pada kuadran ini dianggap kurang penting oleh BMT Pengguna, namun kualitas pelayanan yang diberikan PPOB ABSINDO sangat baik. PPOB ABSINDO mempunyai fee yang kompetitif dan PPOB ABSINDO menjadi sumber informasi kegiatan ke BMT an.

\section{KESIMPULAN DAN SARAN \\ Kesimpulan}

a. Pada sistem PPOB ABSINDO yang telah digunakan oleh BMT pengguna, harapan BMT pengguna PPOB ABSINDO atas kualistas jasa pelayanan (servqual score 23,870 ) lebih tinggi dari kualitas pelayanan dari sistem PPOB yang telah mereka terima (servqual score 22,610). Hal ini menunjukkan adanya gap karena serqual score yang bernilai negative, yaitu sebesar 1,260 Secara keseluruhan kualitas jasa pelayanan sistem PPOB ABSINDO yang diberikan oleh ABSINDO DIY yang merupakan co branding dari PPOB Nusantara belum memenuhi harapan BMT pengguna PPOB ABSINDO. Hal tersebut di tunjukkan dengan nilai $\mathrm{Q}=0,950$

b. Harapan mengenai kualitas jasa pelayanan yang akan diterima oleh BMT pengguna PPOB ABSINDO berbeda dengan kualitas jasa pelayanan system PPOB ABSINDO, harapan tersebut berbeda untuk semua persepsi pada dimensi kualitas jasa pelayanan secara umum PPOB ABSINDO menurut pengetahuan BMT pengguna secara umum.

c. Pada Diagram Kartesius terdapat 2 item pada kuadran $\mathrm{C}$ yang menjadi prioritas untuk melakukan pembenahan yaitu PPOB ABSINDO bebas masalah dan PPOB ABSINDO selalu bertambah fasilitas pelayanannya, dan 2 item pada kuadran D yang menurut sitem PPOB ABSINDO penting namun menurut BMT pengguna harapannya tidak sebesar yang di persepsikan oleh BMT 
pengguna yaitu PPOB ABSINDO mempunyai fee yang kompetitif dan PPOB ABSINDO mampu menjadi sumber informasi kegiatan ke BMT an.

\section{Keterbatasan Penelitian}

a. Penelitian ini menggunakan kuesioner sebagai alat pengumpulan data, tetapi hanya dapat melakukan wawancara secara langsung kepada beberapa responden BMT pengguna saja sehingga kesimpulan yang diambil hanya berdasarkan data yang dikumpulkan melalui kuesioner tersebut.

b. Pengukuran antara harapan dan kenyataan mengenai kualitas jasa pelayanan yang akan diterima oleh BMT pengguna PPOB dilakukan pada waktu yang bersamaan. Hal tersebut mengakibatkan adanya defisiensi skor. Responden memberikan penilaian yang kurang obyektif ketika responden diminta untuk memberikan penilaian harapan dan kenyataan secara bersamaan karena mereka cenderung memberikan skor harapan lebih tinggi dibandingkan dengan skor kenyataan (Cronbach dan Furby, 1970; Wall dan Payne, 1973 dalam Babacus dan Boller, 1992)

c. Penelitian ini tidak meneliti mengenai kualitas jasa pelayanan yang dipersepsikan oleh penyelenggara system PPOB ABSINDO (PPOB Nusantara selaku co branding dari PPOB ABSINDO) yang juga terlibat langsung dalam proses transaksi POB di BMT pengguna.

d. Karena keterbatasan populasi yang ada penelitian ini hanya dibatasi pada 30 (tiga puluh) BMT pengguna PPOB di Kabupaten Bantul, Kabupaten Sleman dan Kota Jogja saja, dari 53 BMT pengguna yang ada di wilayah DIY dan Kalimantan, sehingga hasilnya mungkin tidak dapat digeneralisir untuk seluruh BMT pengguna yang mempergunakan system PPOB ABSINDO

\section{Saran}

Penelitian ini menunjukkan bahwa kualitas jasa pelayanan yang diberikan oleh system PPOB ABSINDO yang merupakan cobranding dari PPOB Nusantara secara umum belum mampu memenuhi harapan BMT pengguna. Hal ini ditunjukkan dengan adanya gap karena servqual score yang bernilai negatif. PPOB Nusantara selaku pihak penyelenggara PPOB ABSINDO dan ABSINDO selaku Asosiasi BMT perlu komitmen untuk mengembangkan budaya kualitas sehingga BMT pengguna mendapatkan kepuasan. Budaya kualitas dapat dilakukan dengan cara perencanaan, pelaksanaan, pemantauan, evaluasi, koreksi dan peningkatan mutu secara terus menerus dan sistematis terhadap semua aspek yang terkait.

Aspek tersebut adalah :

A. Persepsi tentang kualitas jasa pelayanan secara umum tentang PPOB ABSINDO

1. ABSINDO DIY selaku pemilik dan pemegang co branding PPOB Nusantara dengan merk (branding) PPOB ABSINDO hendaknya lebih mengoptimalkan informasi tentang PPOB ABSINDO, bahwa PPOB ABSINDO adalah PPOB yang lengkap dan mudah di gunakan karena ber basis web serta mempunyai fee yang kompetitif dibandingkan dengan PPOB lainnya. Selain itu ABSINDO DIY jika memungkinkan mewajibkan kepada BMT anggota ABSINDO untuk menggunakan PPOB ABSINDO yang merupakan PPOBnya insan BMT dan meyakinkan bahwa PPOB ABSINDO mudah digunakan serta di dukung penuh oleh Bakoel Corporation selaku pemilik dari PPOB Nusantara.

2. ABSINDO DIY selaku pemilik dan penyelenggara ABSINDO DIY mampu menjadikan PPOB ABSINDO menjadi media informasi bagi kegiatan BMT anggota ABSINDO dengan menghidupkan web yang ada serta lebih mempromosikan kelebihan dari PPOB ABSINDO yang ada selama ini yaitu PPOB ABSINDO adalah PPOB yang bebas masalah bisa digunakan kapan saja dan dimana saja selama mempunyai jaringan online yang reliable, selain itu PPOB ABSINDO juga menampilkan fitur yang lengkap dan mudah di fahami, serta memiliki support online yang up to date 
serta tim tehnis yang handal dari PPOB Nusantara.

3. ABSINDO DIY selaku pemilik PPOB ABSINDO bersama dengan Bakoel Corporation selaku pemilik dari PPOB Nusantara sebaiknya melakukan kegiatan yang profokatif untuk menggali lebih dalam tentang PPOB ABSINDO, hal ini dapat dilakukan dengan contoh Pelatihan optimalisasi PPOB ABSINDO bagi BMT anggota ABSINDO DIY yang merupakan BMT pengguna PPOB ABSINDO. Dalam pelatihan tersebut diberikan tips dan trik untuk melakukan transaksi PPOB di loket BMT pengguna, sehingga BMT pengguna merasakan bahwa PPOB ABSINDO selain merupakan PPOB yang mudah di akses, mudah di install, selalu bertambah fasilitas pelayanannya, BMT mitra juga mendapatkan fee dengan cepat, dan dapat secara mudah melakukan konfirmasi deposit. Harapan lainnya adalah BMT pengguna dapat merasakan bahwa mereka selalu dilibatkan dalam kegiatan ABSINDO, serta mendapatkan solusi jika terdapat masalah ketika menjalankan PPOB ABSINDO.

B. Berdasarkan diagram kartesius terdapat 2 item pada kuadran $\mathrm{C}$ yang menjadi prioritas untuk melakukan pembenahan yaitu PPOB ABSINDO bebas masalah dan PPOB ABSINDO selalu bertambah fasilitas pelayanannya, maka hendaknya segera dilakukan pembenahan pada sistem PPOB ABSINDO supaya mampu meminimalkan jumlah masalah yang ada serta di upayakan untuk melakukan penambahan fasilitas pelayanan misalkan fasilitas pembayaran PDAM atau fasilitas lainnya. Sedangkan pada kuadran D yaitu PPOB ABSINDO mempunyai fee yang kompetitif dan PPOB ABSINDO mampu menjadi sumber informasi kegiatan ke BMT an. Dalam hal ini fee dan sumber informasi bukan menjadi masalah tetapi akan lebih baik lagi jika ABSINDO DIY mampu menjadikan sistem PPOB ABSINDO menjadi sumber informasi kegiatan ke BMT an yang memiliki fee yang kompetitif jika diperbandingkan dengan PPOB yang lain.

\section{DAFTAR PUSTAKA}

Humas PT PLN (Persero) Distribusi Jawa Barat dan Banten (2009) Sosialisasi Sistem Payment Point Online Bank Daerah Distribusi Jawa Barat dan Banten

Indriantoro dan Supomo (1999). Metodologi Penelitian Bisnis. BPFE Yogyakarta

Irawati, R. (1998). Pengendalian Kualitas Pelayanan dengan Analisis Servqual Gap pada Stasiun Perumka, Fakultas Ekonomi UGM, Yogyakarta

Ives, B., M.H. Olson and J.J. Baraoudi (1983). The Measurement of User

Information Satisfaction. Communications of the ACM, October: 785-783

Kariningsih, C.S. (1997). Penerapan Analisis Gap dengan Instrumen Servqual

Dalam Rangka Pengendalian Kualitas Pelayanan (Studi pada S1 Reguler FE UGM. Fakultas Ekonomi UGM, Yogyakarta

Kotler, Philip (1997). Marketing Management: Analysis, Planning,

Implementation and Control, Ninth Edition. Englewood Cliffs, Prentice-Hall, Inc:New Jersey

Parasuraman, Zeithaml, A.V. dan Berry, L.L. (1985). A Conceptual Model of

Service Quality. Journal of Retailing, Vol. 67:420-450

(1988). SERVQUAL: A Multiple Item

Scale for Measuring Consumer Perceptions of Service Quality. Journal of

Retailing. Spring: 12-40 
Sonya Mahanani. (2009) Analisis Pengaruh Kualitas Pelayanan terhadap Kepuasan Pelanggan dalam Pembayaran Rekening Listrik (Studi Pada Unit Pelayanan Pelanggan Semarang Barat. Skripsi

Subiyakto, H.H. (1999). Ukuran Kualitas Jasa: Gap Antara Kinerja dan Harapan atau Kinerja?. Wahana, Vol. 2, No. $1: 19-30$

Tjiptono, F. (1999). “Kualitas Jasa: Pengukuran, Keterbatasan dan Implikasi

Manajerial", Usahawan, No. 03: 30-33

Tutut Dewi Astuti, (2005) “Analisis Perbedaan Harapan Kualitas Jasa Pendidikan (Studi Empiris pada Program Studi Akuntansi di Perguruan Tinggi di Yogyakarta) Tesis $S 2$

Zeithaml, A.V. (1988). Consumer Perceptions of Price, Quality and Value: A

Means - End Model and Synthesis of Evidence. Journal of Marketing, Vol. 52: 2-22

Zeithaml A.V., Berry L.L. dan Parasuraman, A. (1988). Communications and

Control Processes in the Delivery of Service Quality. Journal

ofMarketing, Vol.52:35-48

(1988). The Nature and
Determinants of Customer Expectations of Services. Journal of Academy

Marketing Science, Vol. 21, No. 1:1-12 